\title{
Business Sustainability in Bangladesh: An Analysis of Economic Sustainability in Ready-made Garments Industries
}

\author{
Rahima Akter ${ }^{1}$ \\ ${ }^{1}$ Research Officer, Export Promotion Bureau, Bangladesh \\ Correspondence: Rahima Akter, Research Officer, Export Promotion Bureau. Flat G1, Uttara Building, \\ Government Residential Area, Circuit House Road, Ramna, Dhaka, Bangladesh. Tel: 880-1716-020650. E-mail: \\ rahima.ir2006@yahoo.com
}

Received: December 4, 2015

Accepted: December 30, 2015 Online Published: February 25, 2016

doi:10.5539/jms.v6n1p149

URL: http://dx.doi.org/10.5539/jms.v6n1p149

\begin{abstract}
Sustainable business practices are long cherished system that business organizations are expected to exercise to sustain their businesses. The Ready-made Garments industries (RMG) in Bangladesh are now facing this crucial question to adopt a sustainable system in operating their businesses. The more the industry experiences rapid growth, the higher the demand for the implementation of sustainability. Though the experienced and old garments are seen quite well in maintaining this sustainability, the newly established RMG factories are blamed for not having sustainable business procedure, especially economic sustainability which relates to labor standards and labor rights. Despite continuous tremendous pressure from government and international communities, these new establishments often emphasize on profit maximization rather good labor practices. This article examines the business sustainability issues on economy aspects in new generation RMG factories in Bangladesh. This economic sustainability includes the functional strategies regulating the human resources, labor rights and labor conditions of a factory. To study these issues, this research follows the mixed-method research approaches to get better findings of the sampled factories. The study is based on findings of factory level investigation and analysis of in-depth semi structured interviews and focus group discussions (FGD). The results of factory visits show that most of the investigated factories are lack of implementation of economic sustainability. The findings from interviews and FGD revealed underlying causes of this lack of implementation.
\end{abstract}

Keywords: business sustainability, economic sustainability, ready-made garments, labor practices, compliance

\section{Introduction}

Business Sustainability is still an evolving issue in least developed countries especially countries with fast growing trade. The Sustainability term often conflicts with the better known idea Corporate Social Responsibility (CSR) in these third world countries. Sustainability is a wider and more acceptable procedure for business than CSR as sustainability has the longer-term perspective and future-orientation. This broader concept includes not only the impacts of business to natural environment but also other aspects of business environments (Carroll \& Buchholtz, 2014). Considering this increasing attention on sustainable business procedure, implementing the right business strategies that reflect sustainability is quite a difficult task for the suppliers from low-labor cost countries. The Ready-Made Garments (RMG) industries in Bangladesh are often blamed for lack of implementation of business sustainability issues in factories.

Ready Made Garments (RMG) industries in Bangladesh are very important sector in regards to foreign currency earnings and generation. More than $80 \%$ of total export has been earned from this billion-dollar industry in Bangladesh over the last few years (Export Promotion Bureau, 2014-15).Bangladesh is the second largest RMG exporting country in the world and has the competitive advantages compared to its competitors (Berg et al., 2011). There are more than 4 million workforces are engaged in more than 5000 factories (BGMEA, 2015a; BGMEA, 2015b; BKMEA, 2015; Department of Inspection for Factories and Establishments, 2015). These factories are varied in regards to size, experiences, business operation, etc. Many of these are $100 \%$ export oriented with large size, whereas many are small in size but exporting directly. Some firms are working for local suppliers as well as for foreign buyers under subcontracting arrangement and also small in size.

The adoption of Sustainable procedure in business operation is a much needed system for the improvement of business environment in RMG factories in Bangladesh. The lack of implementation of sustainable business 
procedure creates a complicated situation to international audience. The much stated problems that are blamed for are unfair labour practices, violation of workers' rights, unfair labour conditions, insecure building structure, lack of occupational health and workers' safety, environmental pollution etc. The industry is broadly criticized after the tragic events of fire incidents in Tazreen Fashions (in 2012) and the collapse of Rana plaza which housed 4 garmentsin a multi-storied building (BBC, 2013). The issue also came into focus at the end of last century considering the child labor and hazardous working conditions (Nielsen, 2005).

Sustainability is often wrong defined and termed as compliance issues by the RMG industries in Bangladesh. The stakeholders have a misunderstanding about the idea of sustainability and often mixed it up with narrower view of compliance matters. Many companies in Bangladeshbelieve that compliance is the burden on bottom lines. They consider compliance issues as imposed matters rather than adjusting these rules to companies' operational strategies and policies. It is often overlooked that the companies who make sustainability as a goal and can incorporate sustainable business policies to companies' general rules, can achieve competitive advantages compared to their rivals (Nidumolu, Prahalad, \& Rangaswami, 2009).

Though the apparel sector has undergone the major restructuring on building safety, fire and compliance-related issues (Moazzem \& Basak, 2015), there are still a good number of factories who are not aware of sustainable business procedure. These factories are newly established and mostly not interested in spending money to implement good labor practices. Some of these factories are large. Many of these are small in size and working as sub-contract for foreign buyers. But all of these are planning to export directly. This paper notices a problem regarding the sustainability issues in operating these factories. So, the object of this research is-the sustainability issues are not properly implemented in the newly established RMG factories in Bangladesh.

The significance of this problem is immense. Adopting sustainability in business procedure is necessary for not only the fulfillment of buyers' requirements, but to sustain the business into the society in the long run. This is why, the owner and factory management need to admit the problems, recognize the necessity of the sustainable system and adopt the rules, policies and strategies accordingly (Belal \& Owen, 2007). It should be kept in mind that, the importance of the sustainable business system is not based on ethical orientation, but on performance orientation. So, absorbing the sustainability into business procedure has moved away from a macro-social level to an organizational level. Thus, sustainability or CSR influence the financial performance of a company (Carroll \& Shabana, 2010).

This research work is based on the concept of Business Sustainability issues. To what extent the business sustainability specifically economic sustainability of a business is implemented in the RMG factories in Bangladesh. As there are several academic debates about the essence, understanding and implications of the thoughts of CSR, sustainability and other issues, the Section of Literature review contains the conceptual analysis of these thoughts.

The remainder of this paper is organized as follows. This introduction is followed by a brief literature review which contains two parts-conceptual analysises of the theories and the reviews of existing literatures. Section 3-4 describe the purpose of the research and highlight the research questions. These sections are also followed by the Section 5 which specifies Research Methodology and data collection. Section 6 describes and clearly presents: the specific economic sustainability issues-labor standard issues and the conditions of workers' rights. The results of the research approaches and data analysis are presented in the Section 7, namely-Findings and Discussions. The concluding section (Section 8) includes the Research Limitations of the study.

\section{Literature Review}

\subsection{Conceptual Analysis}

Sustainability, Triple-Bottom-Line (TBL) and Corporate Social Responsibility (CSR) have the same aspects and application considering the broader meaning of these three. The TBL approach and Sustainability have strong link. Both approaches consider that firms have-financial, social and environmental - three different types of duties which are termed as 'people, planet and profits' (Elkington, 1998). CSR refers to a set of responsibilities relate to corporate (firm) and social perspective. The lack of well-defined definition and wide range of uses make this term quite complicated with different terms (Carroll \& Shabana, 2010; Frankental, 2001; Garriga \& Mele, 2004; Carroll \& Shabana, 2010) identified four major types of responsibilities. These are economic (e.g., provides profit for shareholders, jobs for employees, product/ service for customers); legal (e.g., obey the laws and rules related to business); ethical (e.g., comply with moral rules and avoid harms) and discretionary (e.g., provides environmental and societal help, voluntary activities). 
As like as CSR view, in Sustainability, the economic activities include business operation, employee management, profit maximization etc.; society means business relationship with society, community involvement, social responsibilities because of impact of business activities, welfare activities etc.; and ecological aspects describe the environmental impact of business activity on the maintenance of the ecology (Fallon, 2013). Balanced approaches by minimizing possible conflict among these three aspects are expected to drive the development and increase the competitiveness of the business by innovation (Giddings, Hopwood, \& O'brien, 2002).

But the harmonization and balancing of these types of responsibilities is quite complex and requires organizations to integrate sustainability at multiple levels and throughout the organizational system. The firm needs to incorporate sustainable approach to its decision making process and organizational strategies ratherthan simply complying with legal and regulatory requirements. The organization's vision needs to reflect the organization's commitment to sustainability. Bonn \& Fisher (2011) identifies three types of organizational strategies at corporate, business and functional level. Corporate level includes overall scope of the firm, business level deals with individual business units and functional level means operations, finance, human resource management, marketing etc. A sustainability seeking organization needs to incorporate sustainable business view in all these strategic levels.

Compliance is mostly related to laws, rules and regulations, requirements of industries and organizational standards and codes of conduct which are to be met accurately. But sustainable business procedure is a wider concept to be embraced with businesses' overall goal and objectives and organizational strategies. Thus, the organizational culture becomes more proactive to move the organization further to be a sustaining corporation (Dunphy, Griffiths, \& Benn, 2003).

\subsection{Gap in Existing Literatures}

While searching for related research on sustainability issues in garments sector, it was very hard to find an original one. Although a set of research on environmental aspects of sustainability is available (Sobhani, Amran, \& Zainuddin, 2009; Belal, 1999), the actual research on firm's economic sustainability is absent. There is also presence of articles which represents the possible conflicts between economic and social sustainability of businesses (Imam, 2000; Belal, 2001). Most of the researcher failed to draw a clear distinction between firms economic and social sustainability issues in business operation. Thus the study on economic sustainability issues in developing country suppliers is extremely limited.

As stated above, manyresearches, e.g., Ahmed (2013) and Moazzem \& Basak (2015) analyse the term 'Compliance' instead of sustainability issues of business. Ahmed (2013) viewed social compliance as a broad concept by combining factories'building standards, working conditions, workers' rights, workers' health and safety measures and environmental safety issues The article also suggested effective monitoring and surveillance system (EMSS) model to establish social compliance. Moazzem \& Basak (2015) hasdone an exploratory research based on interview with 15 suppliers and buyers of garments industries. Though this study indicated that the supplier and buyer should have the system to allocate the margin of profits to establish the compliance issues, the research also combine the physical and social compliance of garments factories. Both studies couldn't discuss the broad aspects of sustainability. There is also lack of study based on primary research or direct tour to garments factories. While the second one of above studies is based on physical visit to the factories, the first one avoided those for inaccessibility of the factories.

Another exploratory research is done by Huq, Stevenson, \& Zorzini (2014) on social sustainability which includes human rights, health and safety and community onfour RMG suppliers in Bangladesh and the Bangladeshi buying houses of two large UK retailers. Though this study significantly identified sustainability and analysed the relationship between productivity and improved social standards in the factories, it also failed to clearly divide the economic and social strategies of a firm. This article also included too broad aspects into one term (social sustainability) which also focused that very few articles about sustainability are based on developing country context (Belal, 1999; Fox, 2004). As a result, most studies failed either to collect data on physical visits or to divide the firm's role to economic and social sustainability distinctively. In view of this, this study aims to understand the issues of economic sustainability in the RMG industries in Bangladesh through practical data collection.

\section{Research Purpose}

The purposeof this study is to analyze and understand the business sustainability issues on economy aspects in newly established Ready-Made Garments (RMG) industries in Bangladesh. 


\section{Research Questions}

This study has set a few questions to answer and thus the result will be the findings of this research. These questions are divided into one central question and a few specific questions.

The central question is-What is the condition of economic sustainability in new generation RMG factories in Bangladesh?

As stated above, business or economic sustainability issues include the functional strategy of a company. Functional strategy means strategies regulating the human resources issues, labor rights and labor conditions of a factory. So, to understand the sustainability issues, we need to examine the present conditions of labor standards and labor rights of a factory.

\section{Specific Questions are}

RQ1. What is the condition of labor standard issues in newly established RMG industries in Bangladesh?

RQ2. How are the workers' rights in these factories exercised?

RQ3. How does the factory management consider the economic sustainability?

\section{Research Method}

According to the nature of the problem and the procedure for data collection, this research has followed a combined method of quantitative and qualitative research. It is assumed that only quantitative data will not be sufficient to achieve the purpose of research. An integration of quantitative and qualitative methods (Bryman, 2006) will be suitable to explain the problem more practically. It is necessary to understand the typology of this mixed-method research as this will clarify the procedure of this research. Neither the quantitative nor the qualitative will be given the priority (Morgan, 1998), rather both methods will be integrated in a way that it can be termed as explanatory mixed method research (Creswell, 2003). This multi-strategy research approaches will be applied during data collection, data analysis and data interpretation stages (Bryman, 2006).

The rational of this multi-strategy research is that quantitative method will not be an appropriate method as it would not be possible to make the generalization about the result as the population is huge. The qualitative method also would not be best as the population is diverse and varied according to different categories.

\subsection{Sample}

According to the problem of this research, the focus of the sampling is only on the new generation factories. These factories are exporting or planning to export soon and established since last 06 (six) years. Among the newly established factories, 22 factories were selected randomly for field visits considering the good access to rich data. These were the samples for quantitative data collection. All garments were selected considering the establishment time and places of the garments prone area.

However, for qualitative data collection, the samples were selected purposively. To get better understanding of the problems, the samples were selected among those 22 samples. As this research followed the explanatory mixed research designs, the samples that suits the purpose mostly, were selected for the samples of qualitative data collection. Two garments, that revealed best and worst situation through the investigation result, were selected for interview. One garment was selected for focus group discussion that was medium condition according to questionnaire data.

It should be kept in mind that both quantitative and qualitative data collection was facilitated by the easier access of author's official identity. As this is regular part of job duty to visit the garments factories and the researcher has the authority to inspect the related papers and different sections of a garment, it was possible to inquire the issues regardless the sensitiveness of the problems to a certain extent.

\subsection{Research Instruments and Data Collection}

Factory-level visits had been carried out in order to collect primary data. A structured-questionnaire (Rowley, 2012) was designed highlighting the purpose and questions of this research. The questionnaire was developed and refined on the basis of original instruments used by different private/public organizations and examining the objectives of this research.The Investigations and surveys have been done during April-November 2015.

Conducting interviews is a way to understand the explanation of certain behaviors or incidents in business research (Saunders et al., 2009). Case studies allow a problem that is in infancy stage to have a thorough analysis of a complex phenomenon in a real-life situation and can provide in-depth insight (Yin, 2009). The interviews had been conducted for case studies in informal discussion and allowed the respondents to talk in-depth about 
the management system. These interview and discussions had been done with a focus on 'how' and 'why' research questions (Baxter \& Jack, 2008). Focus group discussion had also been used as primary sources.

The participants for the study includedare factory owner, manager, managing director, factory officials, supportstaff.The qualitative data collection (interview and FGD) were done after visiting the garments and then a second round trips were done to complete the interview and FGD. As the rapport was build (De Ruyter, 1996; Morgan \& Spanish, 1984)) up during first visit, the qualitative data collection became smooth during the second round. All of the interviews and FGD were done by the researcher, but factory level investigationswere associated with two more colleagues. Almost half of the factory tours were done by the author, rest of factories were visited by two more colleagues. As the questionnaire is highly structured and clearly restricted (Rowley, 2012), it was not difficult for the non-researcher to collect all of those.

\subsection{Data Analysis}

Considering the strategy of this research, the collected data will be analyzed in two ways (Creswell, 2009). The data from the questionnaires, which collected through factory level investigation, was interpreted through the statistical table and numbers. The data was converted into numbers or codes (Dey, 2003) and was analyzed using statistical software. To understand the nature of the samples, the initial part of the analysis consists of samples analysis using graphs, descriptive statistics. This quantitative data analysis highlighted two research questions RQ1 and RQ2. The case studies, the qualitative data, were interpreted using data from questionnaire of specific garments visit and information from the in-depth interview. The findings from FGD also associatedwith this part, analyzing factory visits data first. These both qualitative data answered to the RQ3.

Finally, it was important to be aware of potential biases (Miles, 1979) when analyzing the case study and FGD data. There was a risk from the interview and FGD respondents that they may exaggerate the information of degree of economic sustainability and create a positive image of their factory. This was checked and minimized by supporting documents. This was considered while interpreting the data and drawing conclusions.

\section{Economic Sustainability Issues for RMG Industries in Bangladesh}

A brief discussion on specific Economic Sustainability is helpful to understand the labor standards and labor rights conditions in garments factories in Bangladesh. Economic sustainability, as stated above, includes company's business operation system, strategies for the management of human resources, monitoring of supply chain management and above all profit maximization and income generation process of a business (Langley \& Mellor, 2002). This research narrows down the topic to collect rich and concrete data. The Figure 1 depicts the factors that this study has examined as the part of economic sustainability. 


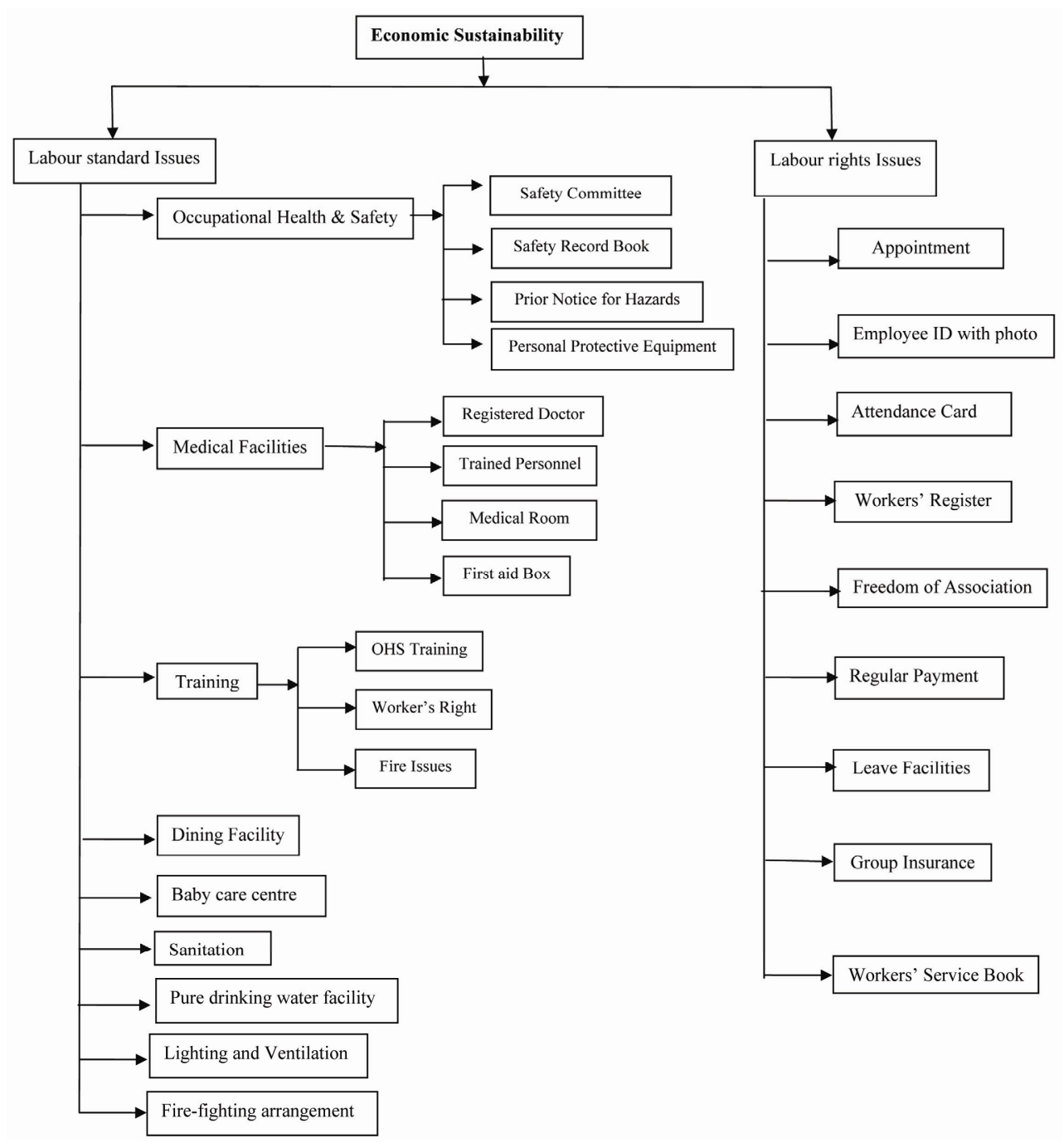

Figure 1. The areas of employee management in economic sustainability

\subsection{Laborstandard Issues}

According to Bangladesh Labor Act 2006 and the recently-framed Bangladesh Labor Act Regulations 2015 (Ministry of Labor and Employment, 2015) existing factories have to form safety committees within six months from the date the rules come into effect while the factories, set up after the formulation of the rules, within nine months after production starts. The administration will arrange the personal protective equipment etc. for the workers and those are placed in right places.

The factory management may arrange medical facilities, e.g., first aid box, separate medical room for workers, trained personnel in case of no regular doctor or nurse. According to Bangladesh's laws, the factory workers should be trained on Occupational Health and Safety, workers' rights and fire issues. The factory management should have the arrangement for baby care center, dining, separate and enough toilets for male or female workers, pure drinking water etc. for the management of workers effectively. There will be arrangement for enough fire-fighting equipment and emergency exit in the factory building to create safe working environment. The lighting and ventilation condition inside the factory should be at satisfactory level.

\subsection{Labor Rights Issues}

According to International Labor Law (ILO) and Bangladesh Labor Act 2006, the employee or worker has the right to get a formal appointment letter. There should be an employee ID card with photo and attendance card, so that they can easily count the number of working days they work for the company. The factory management should maintain workers' register. The payment should be regular. They will be entitled for different kinds of 
leaves facilities according to their job status.

One much stated workers' right is the arrangement of voice representation or freedom of association. Workers should have facility to raise their voices through formation of Trade Union (TU) or Workers Participation Committee (WPC). According to the labor law rules, trade union leaders will nominate the workers' representatives while workers participation committee will do the same if there is no registered trade union in factories. The workers' representatives will be elected in presence of the chief inspector in absence of both TU and WPC. But in many factories, many workers who try to form unions to address violation of workers' rights face threats, intimidation, dismissal and sometimes physical assault at the hands of factory management or hired third parties (Human Rights Watch, 2015).

They also arrange for group insurance so that the emergency incidents may be covered with this insurance. According to set rules, the factory should have group insurance arrangement via BGMEA, so that BGMEA is responsible to arrange insurance fee for the workers after accidents. The factory management may also maintain the workers' service book for keeping skilled workers tied with the factory by providing service benefits.

\section{Findings and Discussions}

This Section is comprised of a brief analysis of Samples selected for the Observation, Information Collection through Questionnaire, Interviews and Focus Group Discussion (FGD). The analysis part will highlights the findings of the Research Questions. It is also envisaged to bring forward the undiscovered truth of the underlying causes of the problems into lights through Interviews and FGD. This Section also includes the discussion of the findings.

\subsection{Sample Description}

According to research design, the selected samples are new generation garments factories. As of Figure 2, a good number of selected factories were established in the year of 2013 and 2014. Among the sampled garments, 9 were established in 2014 and 8 were in 2013. A total of 2 were set up in 2012. The rest of the three were set up in 2011, 2010 and 2009.

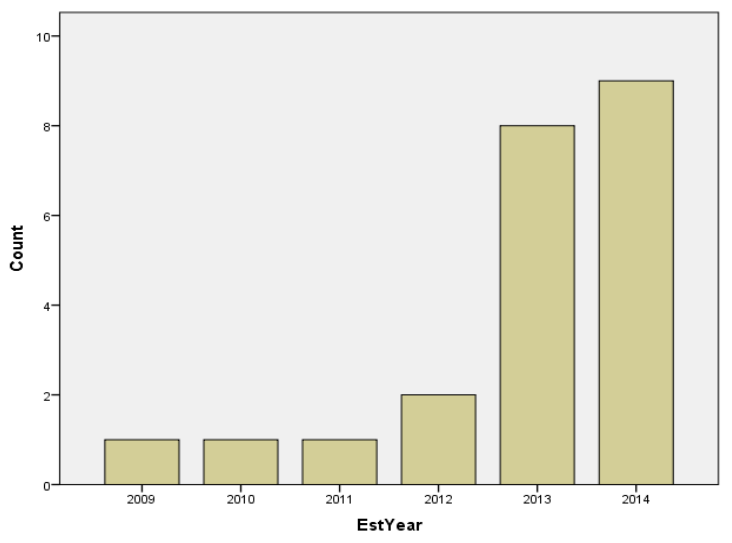

Figure 2. The establishment year of the selected garments factories

The production capacity of these selected sampled factories is varied diversely. The Table 1 displays the production capacity per day into pieces, which was ranged from 300 pieces to 10,000 pieces, the average was $3,513.64$ and the standard deviation was 2,577.244 pieces per day. It means the production capacity of the sampled factories was very diverse. The total workers range from 75 to 1,500 workers, displaying a mean of 369.77 of the sampled factories and a standard deviation of 352.736, which also included that average variation of total workers of selected factories were high. The data also showed a clear dominance of female worker compares to male worker of the garments industries. 
Table 1. Descriptive statistics of production capacity and workers of the selected factories

\begin{tabular}{llllll}
\hline & $\mathrm{N}$ & Minimum & Maximum & Mean & Std. Deviation \\
\hline Production Capacity per Day & 22 & 300 & 10000 & 3513.64 & 2577.244 \\
Total worker & 22 & 75 & 1500 & 369.77 & 352.736 \\
Female worker & 22 & 60 & 1100 & 285.00 & 271.762 \\
Male worker & 22 & 15 & 400 & 84.77 & 87.471 \\
Valid N (listwise) & 22 & & & & \\
\hline
\end{tabular}

According to the following Figure 3, almost half of the selected factories were set up in the Gazipur districts (a total of 10). The second largest portion of the total sampled factories is situated in Dhaka city (a total of 6). There are three factories in Narayangonj and two factories in Savar. Only one factory was visited in Narshingdi district.

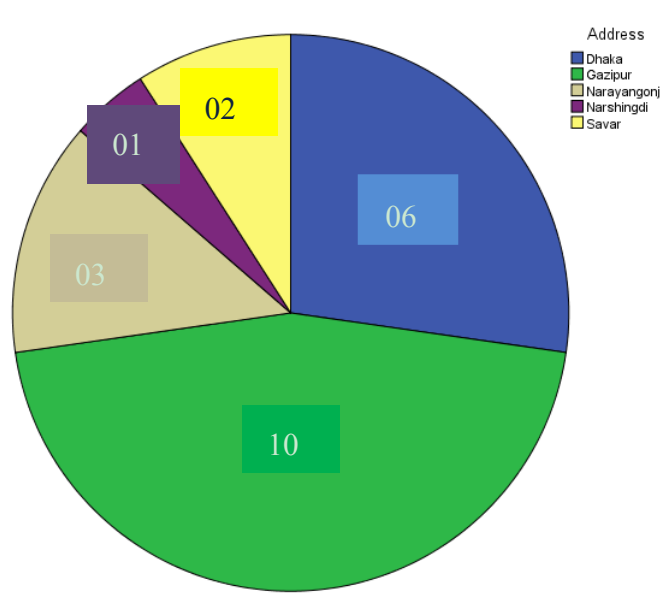

Figure 3. The areas of garments factories

\subsection{Labor Standard Issues in New Generation Factories (RQ1)}

As stated above, labor standard issues, which are defined in nine (9) different areas, were examined through observation, inspecting documents and discussion with factory management. This study found that sampled factories are quite lag behind with the implementation of occupational and health safety (OHS). Only $13.7 \%$ of selected factories (representing 3 factories) have the safety committee in the factories, $18.2 \%$ factories (representing 4) have safety record book, 9.1\% (representing 2) factories give prior notice to workers about hazards, but $63.4 \%$ factories (representing 14) have the arrangement for Personal Protective Equipment (PPE) for their workers (Table 2). For medical facilities, a major portion of selected factories have the arrangement for first aid box ( 20 factories, representing $90 \%$ of total sample) for the injured workers. But, most of the factories do not have the registered doctors $(81.1 \%)$ or trained personnel $(79.2 \%)$, though they have the separate room for medical assistance (50\%).

According to the Table 2, the factories arrange or sent their workers for fire-fighting training more compare to OHS and worker' rights. A total of 17 factories, which include factory management and workers, have received the training on fire-fighting techniques whereas the personnel of 9 factories got training on OHS and a very few (employees from 3 factories) have the training on workers' rights. Most of the factories have the arrangement of fire-fighting equipment (more than $90 \%$ of the selected factories) and emergency exit.

The sanitation facilities and separate toilets at the sampled factories are quite good, but those are not enough for the male-female workers (36.6\% of the sampled factories). Almost half of the companies do not have the dining facilities and baby care room for the workers (55.5\% of the sampled factories in each), though half of these factories have the equipment for baby care room. Lighting and ventilation system at the floors in many factories found quite well (in a total of 16 factories), same as the arrangement for pure drinking water facility for the workers (in 17 factories of the total sample). 
Table 2. The findings on labor standard issues

\begin{tabular}{|c|c|c|c|c|}
\hline Sl. No. & Name of Factors & Yes $(\%)$ & No (\%) & Total \\
\hline \multirow[t]{5}{*}{1.} & Occupational Health \& Safety (OHS) & & & \\
\hline & Safety Committee & $3(13.6 \%)$ & $19(86.4 \%)$ & $22(100 \%)$ \\
\hline & Safety Record Book & $4(18.2 \%)$ & $18(81.1 \%)$ & $22(100 \%)$ \\
\hline & Prior Notice for Hazards & $2(9.1 \%)$ & $20(90.9 \%)$ & $22(100 \%)$ \\
\hline & Personal Protective Equipment & $14(63.4 \%)$ & $8(36.6 \%)$ & $22(100 \%)$ \\
\hline \multirow[t]{5}{*}{2.} & Medical Facilities & & & \\
\hline & Registered Doctor & $4(18.2 \%)$ & $18(81.1 \%)$ & $22(100 \%)$ \\
\hline & Trained Personnel & $6(79.2 \%)$ & $16(20.8 \%)$ & $22(100 \%)$ \\
\hline & Medical Room & $11(50 \%)$ & $11(50 \%)$ & $22(100 \%)$ \\
\hline & First Aid Box & $20(90.9 \%)$ & $2(9.1 \%)$ & $22(100 \%)$ \\
\hline \multirow[t]{4}{*}{3.} & Training & & & \\
\hline & OHS & $9(40.9 \%)$ & $13(59.1 \%)$ & $22(100 \%)$ \\
\hline & Workers' Rights & $3(13.6 \%)$ & $19(86.4 \%)$ & $22(100 \%)$ \\
\hline & Fire Fighting & $17(77.3 \%)$ & $5(22.7 \%)$ & $22(100 \%)$ \\
\hline 4. & Dining Facility & $10(54.5 \%)$ & $12(55.5 \%)$ & $22(100 \%)$ \\
\hline \multirow[t]{3}{*}{5.} & Baby Care Centre & & & \\
\hline & Facilities & $10(54.5 \%)$ & $12(55.5 \%)$ & $22(100 \%)$ \\
\hline & Equipment & $5(22.7 \%)$ & $5(22.7 \%)$ & $10(50 \%)$ \\
\hline \multirow[t]{4}{*}{6.} & Sanitation & & & \\
\hline & Facilities & $22(100 \%)$ & - & $22(100 \%)$ \\
\hline & Separate Toilets & $22(100 \%)$ & - & $22(100 \%)$ \\
\hline & Enough Toilets & $14(63.4 \%)$ & $8(36.6 \%)$ & $22(100 \%)$ \\
\hline 7. & Pure Drinking Water Facility & $17(77.3 \%)$ & $5(22.7 \%)$ & $22(100 \%)$ \\
\hline 8. & Lighting and Ventilation & $16(63.4 \%)$ & $8(36.6 \%)$ & $22(100 \%)$ \\
\hline \multirow[t]{3}{*}{9.} & Fire Fighting Arrangement & $22(100 \%)$ & - & $22(100 \%)$ \\
\hline & Equipment & $21(95.5 \%)$ & $1(4.5 \%)$ & $22(100 \%)$ \\
\hline & Emergency Exit & $22(100 \%)$ & - & $22(100 \%)$ \\
\hline
\end{tabular}

\subsection{Labor Rights Issues that Exercised in Sampled Factories (RQ2)}

As of basic rights of an employee, most of the appointment in the selected factories is informal. The observation found that $68.2 \%$ of the sampled factories provide no appointment letter to their workers. Same as, employee ID card with photos, the factories seemed quite reluctant to provide workers' ID card with photos, a total of 13 factories (59.1\% factories) do not arrange ID card for their workers. Rather these factories provide attendance cards (13 factories) with less than half of these (5 factories) are not updated. Almost all of the selected factories maintain the worker's register (21 factories of total 22), but one-third of these are updated only (Table 3 ).

Table 3. The findings on labor rights issues

\begin{tabular}{lllll}
\hline Sl. No. & Name of Factors & Yes (\%) & No (\%) & Total \\
\hline 1. & Appointment/Recruitment & & \\
& Formal & $7(31.8 \%)$ & \\
& Informal & $17(68.2 \%)$ & & $22(100 \%)$ \\
\hline 2. & Employee ID card with photo & $9(40.9 \%)$ & $13(59.1 \%)$ & $22(100 \%)$ \\
\hline 3. & Attendance Card & $13(59.1 \%)$ & $9(40.9 \%)$ & $13(100 \%)$ \\
\hline & Updated & $5(40 \%)$ & $8(60 \%)$ & $22(100 \%)$ \\
\hline 4. & Workers' Register & $21(95.5 \%)$ & $1(4.5 \%)$ & $21(100 \%)$ \\
\hline 5. & Updated & $7(31.4 \%)$ & $14(63.6 \%)$ & $22(100 \%)$ \\
& Voice Representation/Participation Committee (WPC)/Trade Union & $3(13.6 \%)$ & $19(86.4 \%)$ & $22(100 \%)$ \\
\hline 6. & (TU)/Freedom of Association & & & $22(100 \%)$ \\
\hline 7. & Regular payment & $18(81.1 \%)$ & $4(18.2 \%)$ & $22(100 \%)$ \\
& Leave Facilities & $20(90.9 \%)$ & $2(9.1 \%)$ & $4(18.2 \%)$ \\
& Leave Register & $4(18.2 \%)$ & $18(81.1 \%)$ & $4(18.2 \%)$ \\
& Casual Leave & $4(18.2 \%)$ & - & $4(18.2 \%)$ \\
& Earn Leave & $4(18.2 \%)$ & - & $4(18.2 \%)$ \\
\hline 8. & Sick Leave & $4(18.2 \%)$ & - & $22(100 \%)$ \\
\hline 9. & Maternity Leave & $4(18.2 \%)$ & - & $22(100 \%)$ \\
\hline
\end{tabular}


According to the Table 3, only $13.6 \%$ of total investigated factories (representing 3 factories) have the voice representation. Though most of the factories ( $81.1 \%$, representing 18 factories) have the regular payment system, but very few of them are maintaining workers' service book and group insurance for workers $(18.2 \%$, representing 4 factories). $90.9 \%$ factories have the leave facilities, but they don't have the register system to count the types of leaves, only 4 garments were found to maintain leave register.

7.4 The Economic Sustainability and the Factory management (RQ3): Case studies and Focus Group Discussion (FGD)

Three garments factories, among the selected sample of 22 , had been chosen for the in-depth analysis through case study and focus group discussi onto understand the view of factory management about the issues of economic sustainability, the underlying causes of not managing those issues and their future concern on economic sustainability. The basic questions for interview and FGD were: how the factory management and staffs consider the economic sustainability at their factory, why they are not able to implement the issues of the economic sustainability, and how they will materialize sustainability in future. This section will present the results of the case studies and FGD including the findings of the questionnaires of factory visits. For both the process, factory workers were not included for interview and discussions.

For case studies, in-depth interview and discussions were done with higher level factory management. One garment factory, named here is as the Factory V (The real name is not disclosed here due to the ethical consideration of this study) is situated in Dhaka district, far from Dhaka city corporation area, and established in 2009. Another factory has been selected inside the Dhaka city (at Mirpur), here named as Factory B, is established in 2014 as exporter though worked as sub-contract since last few years. While the first one is large in size and situated at open field in a village area of Dhaka district, the other one is housed in a rented and shared residential building in a busy area of Dhaka city.

The data through the Questionnaires results that economic sustainability is better exercised in Factory V compare to Factory B. Though both the garments do not have the safety committee and safety record book to maintain the OHS issues, Factory Bdo not have the system for prior notice of hazards and PPE. Factory V is very good in maintaining all issues of labor standards and labor rights related to this research except the formation of trade union or WPC for the workers. As the garment shifted from a busy area to big industrial site, it was quite possible for the company to ensure all the facilities, e.g. baby care centre with equipment, medical room, dining room, permanent arrangement for pure drinking water,enough and separate toilets for the workers including playground for the workers' children. The production section is in separate tin shade big house with enough gates and windows. This house is surrounded by varanda including an open space which they term as 'Assembly' place for fire or any kind of accidental incidence. Fire-fighting arrangements are very good including a set of trained staffs.

While inspecting the papers related to labor rights, it is found that this factory has the formal appointment system including employee ID card with photo, attendance card, updated workers' register, service book, leave register, group insurance and regular payment system.

However, Factory B is found comparatively worse situation as like as other garments factories inside Dhaka city. It doesn't have OHS system, medical facilities (except first aid box) and training to workers (except fire training). This factory doesn't have the facilities for pure drinking water, baby care, dining etc. The lighting and ventilation is also not good. The toilets are not enough and not separated for male and female workers. The Factory B is lag behind on fire-fighting arrangement, especially emergency exit was found too much narrow, rather creating another risk for the workers while using in case of emergency.

For labor rights issues, Factory B doesn't have the formal appointment system including employee ID, attendance card and leave register. The workers register is not updated and there was no group insurance system and workers service book. Obviously, the factory doesn't have any voice representation arrangement for the workers.

The General Manager (GM) of Factory V and the Manager of the Factory B, were interviewed and discussed with about the research issues.

The detailed and in-depth interview and discussion revealed several insights about the condition of economic sustainability at both garments. The above data of both garments shows that Factory $\mathrm{V}$ is more interested to implement the economic sustainability issues than Factory B. During the interview, the GM of Factory V expressed that the labor standard and labor rights issues need to be implemented to get more output from the workers. During the visit, the workers were found with factory uniform with enough room to work comfortably. 
Conversely, a discussion was held with the Factory B management about the working environment especially dumped garments wastage at the stairs and other exits and also the sanitation system for workers. The explanation gave an insight about the reluctance of management for creating workers friendly environment inside the factory. They consider the compliance issues are regulatory bindings with the Government and imposed matters from buyers.

The GM explained, "not only the good working environment, we arrange the transports [the bus] for the workers to come here from the city. Otherwise we can't ensure the skilled workers to remain working with us." Conversely, the Manager of Factory B, on this issue informed that, "the owners are not very much interested to interfere all these [to create dining space, separate toilets, or attendance card] matters [......] as these do not affect our production [......] we are also not afraid of skilled workers, as there are available workers in this area [in Mirpur]."

With close observation during the visit and interview, it is found that the relationship between staffs/management and workers is very poor, even in a good compliant factory (like Factory V). The staff uses bullying, threats and harassment to ensure rules of compliance and increase productivity.

The Focus Group Discussion (FGD) was organized in a factory, here referred as Factory G, which is situated in Gazipur and established in 2013. The participants of the discussion were the factory owner who is also Chairman and Managing Director (MD) of the factory, commercial officer, production supervisor, and staff working at admin \& accounts section.

According to data from the Questionnaires, this garment doesn't have the OHS system and no registered doctor. But it has trained medical personnel, medical room and first aid box. The workers do not have the training on OHS and workers' rights except fire issues. There were no dining space, pure drinking water and baby care facility at thegarment. The sanitation facilities were not enough though toilets are separate. Fire-fighting arrangement and lighting and ventilation were quite good. The factory didn't have the formal appointment system and employee ID card with photos. The garment had the Attendance card, workers' register and leave register but those were not updated. It didn't have any WPC, group insurance and workers' service book.

Though the factories are not economically sustainable, it is comprehended that factory management are somewhat aware of the importance of better labor practices. The reason is that they wouldn't be able to attract the skilled labor or sustain the productivity without ensuring good labor issues. The MD explained, "if I can't ensure the good systems and basic rights for these worker I cannot expect that they will stay at my factory [.....] here [in Gazipur] a lot of garments factories and they [the workers] have the opportunities to work anywhere. [.......] that's the workers are floating here and without good environment it is very difficult for us to keep them to work with us".

During the FGD, it was also revealed that factory staffs consideredeconomic sustainability as government or other authority's rules which should be implemented whenever need, not the regular part of business procedure. They have the systems, e.g., workers' register, workers' attendance card, leave register etc. but those are not updated. The MD became angry with his staff as they were not maintaining those and he is not aware of that.

Answering to the future involvement, the owner informed that they were planning to move from this busy area to a more spacious area to ensure the good labor issues. Regarding sustainability, the statement of the owner is praise worthy, "I have never think of a company where my workers will leave my factory because they are not happy with my system [.......] I always dream a company where I will accommodate with thousands of workers and they will stay as this is the best factory in surrounding areas."

\subsection{Discussion of the Findings}

The data from quantitative study or factory visits, displays that most of the investigated firms are lack of implementation of economic sustainability, e.g., labor standard issues and labor rights issues. Some labor standard issues (e.g., pure drinking water facility, child labor, fire-fighting arrangement etc.) are quite good condition compare to labor rights issues. This is perhaps because of the close observation by different authority to implement those (Moazzem \& Basak 2015). The scenario also indicates the focus of those issues that are necessary to get the permission of factory set up.

One important observation is that the factories in Dhaka city are worse than factories in other areas. These factories were suffering form not only being overcrowded, unhygienic, bad working environment but also having unfriendly and anti-compliant management for the workers.

The poor performances may be associated with the ignorance and unawareness of the necessity of the issue (Baden, Harwood, \& Woodward, 2009). Based on qualitative data analysis, it can be concluded that 
organizational culture is very important to implement the economic sustainability issues (Hofstede \& Hofstede, 2005). Factory management and the staff do not have the mind set to continue good business practices. The management and staff think themselves as most powerful and thus behave with workers. Most of the cases, economic sustainability is not ensured due to their perception of the business procedure-to maximize the profit with neglecting the workers' issues that not directly linked with earnings.

Very few garments were found with all facilities including updated information. It seems they created these facilities to get the required license form certain authority during the start-up process of the business. Now they are quite reluctant to maintain all of those regularly. They consider those during the inspection of concerning authority to get the license renewed properly.

\section{Limitations and Future Research}

This study faces some limitations while collecting data and interpreting those. These limitations are, in a broad sense, two folds. The workers are the core part of a factory and engine of the total business procedure. To understand their experience, feelings and condition about the labor practices, it was necessary to collect their views and comments. The life cycle and social adjustment of a worker could be an extended part of this research.

Another one is that this research should include the budget allocation to ensure business sustainability by factory management and the buyers. A percentage of company's profit should be allocated to ensure good labor practices by the factory management. As well as the buyer also should monitor the sustainable business system in their value chain and to ensure that they should include these cost into pricing. These are should be researched in-depth way in future.

\section{Acknowledgement}

I wish to thank Dr. Mohammad Lutfor Rahman, Assistant Professor, Institute of Statistical Research and Training (ISRT), University of Dhaka, for assistance in statistical analysis and helpful advice in selecting the method of research.

\section{References}

Ahmed, F. (2013). Could monitoring and surveillance be useful to establish social compliance in the ready-made garment (RMG) industry of Bangladesh? International Journal of Management and Business Studies, 3(3), 88-100. Retrieved from http://internationalscholarsjournals.org

BBC (2013). Dhaka building collapse: factories and buyers. Retrieved from www.bbc.co.uk/news/world-asia-22474601

Baden, D. A., Harwood, I. A., \& Woodward, D. G. (2009), The effect of buyer pressure on suppliers in SMEs to demonstrate CSR practices: an added incentive or counter productive? European Management Journal, 27(6), 429-441. http://dx.doi.org/10.1016/j.emj.2008.10.004

Belal, A. R. (1999). Social and environmental disclosure in Bangladesh. The Cost and Management, 27(2), $10-14$.

Belal, A. R. (2001). A study of corporate social disclosures in Bangladesh. Managerial Auditing Journal, 16(5), 74-289. http://dx.doi.org/10.1108/02686900110392922

Belal, A. R., \& Owen, D. L. (2007).The views of corporate managers on the current state of, and future prospects for, social reporting in Bangladesh. Accounting, Auditing and Accountability Journal, 30(3), 472-492. http://dx.doi.org/10.1108/09513570710748599

Berg, A., Herich, S., Kempf, S., Tochtermann, T., \& McKinsey. (2011). Bangladesh's ready-made garments landscape: The challenge of Growth. Retrieved from http://www.mckinsey.de/sites/mck_files/files/2011_McKinsey_Bangladesh.pdf

BGMEA. (2015a). Bangladesh Garments Manufacturer \& Exporters Association (BGMEA) website. Retrieved from http://www.bgmea.com.bd/chart_test/number_of_employment_in_garment

BGMEA. (2015b). Bangladesh Garments Manufacturer \& Exporters Association (BGMEA) website. Retrieved from http://www.bgmea.com.bd/member/memberlist\#.VkfJXE2_nIU

BKMEA. (2015). Bangladesh Knitwear Manufacturer \& Exporters Association (BKMEA) Member Profile, BKMEA website. Retrieved from http://www.bkmea.com/member/

Baxter, P., \& Jack, S. (2008). Qualitative Case Study Methodology: Study Design and Implementation for Novice Researchers. The Qualitative Report, 13, 544-559. Retrieved from 
http://www.nova.edu/ssss/QR/QR13-4/baxter.pdf

Bonn, I., \& Fisher, J. (2011). Sustainability: the missing ingredient in strategy. The Journal of Business Strategy, 32(1), 5-14. http://dx.doi.org/10.1108/02756661111100274

Bryman, A. (2006). Integrating quantitative and qualitative research: how is it done? Qualitative Research, 6(1), 97-113. http://dx.doi.org/10.1177/1468794106058877

Carroll, A. B., \& Shabana, K. M. (2010). The Business Case for Corporate Social Responsibility: A Review of Concepts, Research and Practice. International Journal of Management Reviews, 12(1), 85-105. http://dx.doi.org/10.1111/j.1468-2370.2009.00275.x

Carroll, A., \& Buchholtz, A. (2014). Business and society: Ethics, sustainability, and stakeholder management. Cengage Learning.

Clifton, D., \& Amran, A. (2011). The Stakeholder Approach: A Sustainability Perspective. Journal of Business Ethics, 98, 121-136. http://dx.doi.org/10.1007/s10551-010-0538-6

Creswell, J. W. (2003). Research Design: Qualitative, Quantitative, and Mixed MethodsApproaches (2nd ed.). Thousand Oaks, CA: Sage.

Creswell, J. W. (2009). Editorial: Mapping the field of mixed methods research. Journal of Mixed Methods Research, 3(2), 95-108. http://dx.doi.org/10.1177/1558689808330883

Department of Inspection for Factories and Establishments (DIFE) website. (2015). Number of RMG Factories by District. Retrieved from http//database.dife.gov.bd/reports/number-of-rmg-factories-by-district

Dey, I. (2003). Qualitative data analysis: A user friendly guide for social scientists. Routledge.

De Ruyter, K. (1996). Focus versus nominal group interviews: A comparative analysis. Marketing Intelligence \& Planning, 14(6), 44-50. http://dx.doi.org/10.1108/02634509610131153

Dunphy, D. C., Griffiths, A., \& Benn, S. (2003). Setting the agenda for corporate sustainability. Organizational change for corporate sustainability: a guide for leaders and change agents of the future (pp. 3-28, 296-304). London: Routledge.

Elkington, J. (1998). Partnerships from cannibals with forks: the triple bottom line of 21 st century business. Environmental Quality Management, 8(1), 37-51. http://dx.doi.org/10.1002/tqem.3310080106

Export Promotion Bureau. (2015). Annual Statistics 2014-2015. Retrieved from http://www.epb.gov.bd/index.php/home/exportdata

Fallon, W. (2012). Sustainability, stakeholder and the nature of the firm. In Moscardo, G. (ed), Sustainability in Australian business: principles and practice ( pp. 38-44). Australia, Milton, Qld: John Wiley and Sons.

Fox, T. (2004). Corporate social responsibility and development: in quest of an agenda. Development, 47(3), 29-36. http://dx.doi.org/10.1057/palgrave.development.1100064

Frankental, P. (2001). Corporate social responsibility-a PR invention? Corporate Communications, 6(1), 18-23. http://dx.doi.org/10.1108/13563280110381170.

Garriga, E., \& Mele, D. (2004). Corporate Social Responsibility theories: mapping the territory. Journal of Business Ethics, 52, 51-71. http://dx.doi.org/10.1023/B:BUSI.0000039399.90587.34

Giddings, B., Hopwood, B., \& O’brien, G. (2002). Environment, economy and society: fitting them together into sustainable development. Sustainable Development, 10(4), 187-196. http://dx.doi.org/10.1002/sd.199

Hofstede, G., \& Hofstede, G. J. (2005). Cultures and Organizations: Software of the Mind:Intercultural Cooperation and Its Importance for Survival. New York, NY: McGraw-Hill.

Human Rights Watch (HRW). (2015). Whoever Raises their Head Suffers the Most. Workers' Rights in Bangladesh's Garment. Retrieved from http://features.hrw.org/features/HRW_2015_reports/Bangladesh_Garment_Factories/index.html

Huq, F. A., Stevenson, M., \& Zorzini, M. (2014). Social sustainability in developing country suppliers, International Journal of Operations \& Production Management, 34(5), 610-638. http://dx.doi.org/10.1108/IJOPM-10-2012-0467.

Imam, S. (2000). Corporate social performance reporting in Bangladesh. Managerial Auditing Journal, 15(3), 133-141. http://dx.doi.org/10.1108/02686900010319384

Langley, P., \& Mellor, M. (2002). 'Economy', sustainability and sites of transformative space. New Political 
Economy, 7(1), 49-65. http://dx.doi.org/10.1080/13563460120115516

Mitchell, R. K., Agle, B. R., \& Wood, D. J. (1997). Toward a theory of stakeholder identification and salience: Defining the principle of who and what really counts. Academy of Management Review, 22, 853-886.

Miles, M. B. (1979). Qualitative data as an attractive nuisance: The problem of analysis. Administrative science quarterly, 590-601. http://dx.doi.org/10.2307/2392365

Ministry of Labor and Employment. (2015). Acts and Rules, viewed on 28 Sunday 2015. Retrieved from http://www.mole.gov.bd/site/view/legislative_information/Acts-\&-Rules

Moazzem, K. G., \& Basak, K. K. (2015). Margin and Its Relation with Firm Level compliance Illustration on Bangladesh Apparel Value Chain. Retrieved http://cpd.org.bd/wp-content/uploads/2015/08/Margin-and-Its-Relation-with-Firm-Level-Compliance.pdf

Morgan, D. L. (1998). Practical Strategies for Combining Qualitative and Quantitative Methods: Applications for Health Research. Qualitative Health Research, 8, 362-376. http://dx.doi.org/10.1177/104973239800800307

Morgan, D. L., \& Spanish, M. T. (1984). Focus groups: A new tool for qualitative research. Qualitative. Sociology, 7, 253-270. http://dx.doi.org/10.1007/BF00987314

Nielsen, M. E. (2005). The politics of corporate responsibilityand child labour in the Bangladeshi garment industry. International Affairs, 81(3), 558-580. http://dx.doi.org/10.1111/j.1468-2346.2005.00469.x

Nidumolu, R., Prahalad, C. K., \& Rangaswami, M. R. (2009). Why sustainability is now the key driver of innovation? Harvard Business Review, 87(9), 57-64.

Rowley, J. (2012). Conducting research interviews. Management Research Review, 35(3/4), 260-271. http://dx.doi.org/10.1108/01409171211210154

Saunders, M., Lewis, P., \& Thornhill, A. (2009). Research Methods for Business Students. Pearson Education, Harlow.

Sobhani, F. A., Amran, A., \& Zainuddin, Y. (2009). Revisiting the Practices of Corporate Social and Environmental Disclosure in Bangladesh. Corporate Social Responsibility and Environmental Management, 16, 167-183. http://dx.doi.org/10.1002/csr.193

Yin, R. (2009). Case Study Research: Design and Methods. Thousand Oaks, CA: Sage.

\section{Copyrights}

Copyright for this article is retained by the author(s), with first publication rights granted to the journal.

This is an open-access article distributed under the terms and conditions of the Creative Commons Attribution license (http://creativecommons.org/licenses/by/3.0/). 